\title{
Computed tomographic patterns of orbital cellulitis due to sinusitis
}

\author{
Padrões tomográficos decelulite orbitá ria secundá ria à sinusite
}

\author{
Filipe José Pereira ${ }^{1}$ \\ Antonio Augusto Velasco e Cruz ${ }^{2}$ \\ Wilma Teresinha Anselmo-Lima ${ }^{3}$ \\ Jorge Elias Júnior ${ }^{4}$
}

School of Medicine of Ribeirão Preto, University of São Paulo, Brazil.

${ }^{1}$ Master degree and in doctorate in Ophthalmology in São Paulo University - USP - Ribeirão Preto (SP) - Brazil.

${ }^{2}$ Associate professor, Department of Ophthalmology, Otorhinolaringology and Head and Neck Surgery of School of Medicine of Ribeirão Preto - USP - Ribeirão Preto (SP) - Brazil.

3 Associate professor Department of Ophthalmology, Otorhinolaringology and Head and Neck Surgery of School of Medicine of Ribeirão Preto - USP - Ribeirão Preto (SP) - Brazil.

${ }^{4}$ Professor, Department of Radiology of School of Medicine of Ribeirão Preto - USP - Ribeirão Preto (SP) Brazil.

Correspondence to: Antonio Augusto Velasco e Cruz. Faculdade de Medicina de Ribeirão Preto, Departamento de Oftalmologia, Otorrinolaringologia e Cirurgia de Cabeça e Pescoço. Hospital das Clínicas - Campus. Av. Bandeirantes, 3900 - Ribeirão Preto (SP) CEP 14049-900

E-mail: aavecruz@fmrp.usp.br filipejpereira@ig.com.br

Recebido para publicação em 20.06.2005

Versão revisada recebida em 12.12.2005

Aprovação em 10.01.2006

The authors have no proprietary interest in any aspect of this study.

Nota Editorial: Depois de concluída a análise do artigo sob sigilo editorial e com a anuência da Dra. Simone H. D. Von Faber Bison sobre a divulgação de seu nome como revisora, agradecemos sua participação neste processo.

\begin{tabular}{l} 
ABSTRACT \\
\hline Purpose: To describe the CT findings of orbital cellulitis due to sinusitis. \\
Methods: The records and CT scans of 45 consecutive patients with \\
orbital cellulitis due to sinusitis treated at the Hospital of the Medical \\
School of Ribeirão Preto were analyzed by a radiologist and two orbital \\
surgeons. Results: Three major types of CT changes were observed: \\
diffuse fat infiltration, subperiosteal abscess and orbital abscess. Diffuse \\
fat infiltration (characterized by an increased density of the extra- or \\
intraconal fat) was seen in 11 patients (24.44\%). A subperiosteal abscess \\
was diagnosed in 28 patients (62.23\%). A surgically proved orbital \\
abscess was detected in 6 patients (13.33\%). Conclusions: In all cases \\
of orbital cellulitis due to sinusitis intraorbital changes can be detected \\
by CT scans either as a diffuse infiltration of the orbital fat or as a \\
detachment of the periorbita (subperiosteal abscess) or a true orbital \\
abscess. Category I of Chandler orbital cellulitis classification (inflamma- \\
tory edema) must be understood as a stage of a process that is already \\
happening within the orbit and, as the term "preseptal cellulitis" means \\
a palpebral infection, this designation should not be used to stage orbital \\
cellulitis.
\end{tabular}

Keywords: Cellulitis/etiology; Sinusitis/complications; Orbit; Abscess; Computed tomography, x-ray computed

\section{INTRODUCTION}

Orbital infections, which are in general referred to as cellulitis ${ }^{(1-5)}$, can derive from multiple causes such as dental abscess, trauma, closed fractures, periocular surgery, panophthalmitis, septicemia and immunosuppres$\operatorname{sion}^{(6)}$, but in the vast majority of cases they represent complications of sinusitis.

Since the thirties, it has been recognized that orbital cellulitis secondary to sinusitis may have different clinical presentations, and several schemes of classification of these types of orbital infections have been published in the otorhinolaryngological literature ${ }^{(7-11)}$. The most quoted is Chandler's classification published in $1970^{(12-13)}$ and subsequently used in the vast majority of papers on orbital infections ${ }^{(14-23)}$.

Original Chandler's classification of orbital cellulitis comprised five categories. According to the author ${ }^{(12)}$, the five categories are described as follows: group I (inflammatory edema) - "This affects the eyelid with or without edema of the orbital contents... There is no limitation of extraocular movements. There might be a slight proptosis of the globe"; group II (orbital cellulitis) - "Diffuse edema of the orbital contents... There is no 
abscess formation", group III (subperiosteal abscess) - "This refers to a collection of pus between the periorbita and the bony wall of the orbit"...; group IV (orbital abscess) - "A discrete collection of pus forms within the orbital tissues"; group V (cavernous sinuses thrombosis) - "Further extension of the phlebitis posteriorly into the cavernous sinus".

A careful analysis of the terminology used in the orbital cellulitis classifications derived from Chandler's article, shows that they are not exempt from criticism. Most of them were established in the pre-CT era and include palpebral and intracranial pathologic processes under the concept of orbital infection.

In order to classify the radiological patterns of orbital cellulitis, we reviewed the orbital CT scans of 45 consecutive patients with orbital cellulitis associated with sinusitis. From a radiological point of view, all orbital cellulitis forms can be classified into three major categories: diffuse fat infiltration, subperiosteal abscess and orbital abscess.

\section{METHODS}

We reviewed the medical records and $\mathrm{CT}$ scans of 45 patients with orbital infections due to sinusitis who were treated at the Hospital of the Medical School of Ribeirão Preto. As shown if Figure 1, patients ranged in age from 1 month to 65 years (mean $=14.88$, sd 2.15 years $)$.

The majority of patients $(76 \%)$ were under 18 years of age and there was a slight, not significant preponderance of males ( 25 or $55.5 \%$, chi-square $=0.20, \mathrm{p}=0.65)$. All CT scans were performed using a Tomoscan LX/C apparatus (Philips Medical System $\mathrm{W}^{7}$ ). Axial and coronal scans of the orbits and paranasal sinuses were obtained at 3-mm intervals both before and after intravenous injection of contrast material. The films were reviewed by two orbital surgeons and a radiologist.

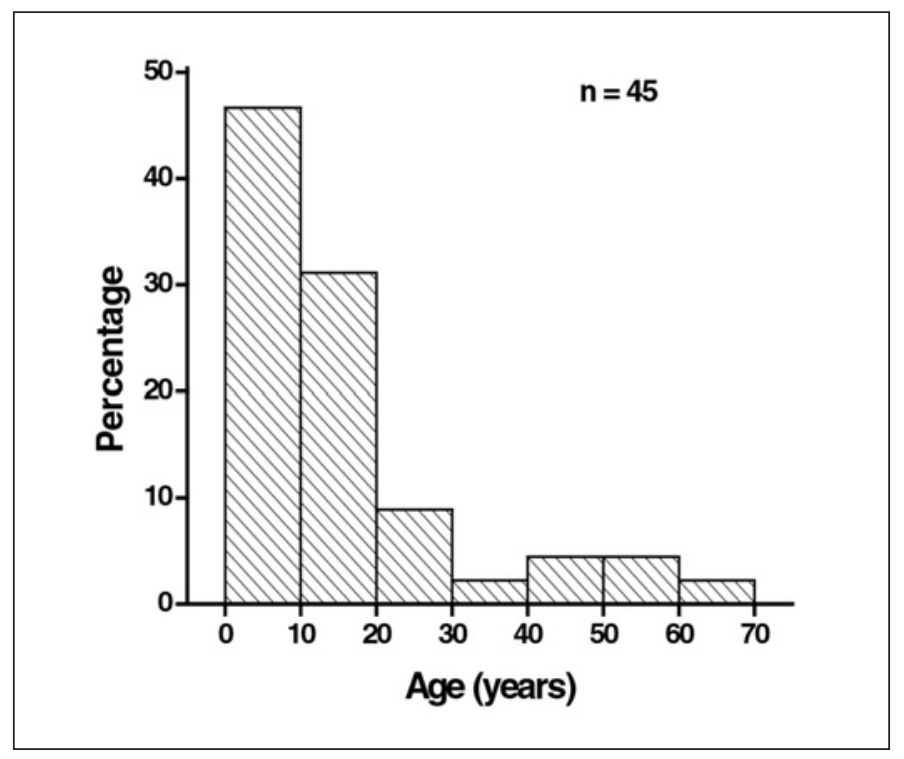

Figure 1 - Age distribution of 45 consecutive patients with orbital cellulitis due sinusitis
In order to categorize the radiological patterns of cellulitis the following guidelines were adopted. Diffuse fat infiltration was characterized by an increased density of the extra- or intraconal fat. The limits of the transition between the normal fat and the enhanced fat density were typically gradual and not well defined. A subperiosteal abscess was diagnosed when the periorbita was elevated from at least one orbital wall adjacent to a paranasal sinus. Finally, an orbital abscess was defined whenever an abnormal heterogeneous density was found (with or without ring appearance) within the orbital fat.

\section{RESULTS}

In all cases the orbital infection was unilateral. The left orbit was involved in $24(53.33 \%)$ of the 45 patients and the right in $21(46.67 \%)$. This difference was not significant (chi-square $\mathrm{p}=0.654)$. Figure 2 shows the distribution of the types of sinusitis associated with the orbital infection. Considering the whole sample, maxillo-ethmoidal and pansinusitis were more frequent. However, when the group was divided into two categories (below and above 10 years) the pattern of sinusitis changes.

When the age continuum was broken down into two categories (below and above 10 years) the pattern of sinusitis changed.

As displayed in figure 3, below 10 years of age there was no case of fronto-ethmoidal infection and the number of pansinusitis was the highest. After 10 years of age, 3 cases of fronto-ethmoidal sinusitis were detected and the occurrence of pansinusitis decreased.

In all cases intraorbital changes could be detected. Diffuse infiltration was seen as an isolated feature in 11 patients $(24.44 \%)$ who were successfully managed using medical treatment with intravenous antibiotics alone (Figure 4). As shown

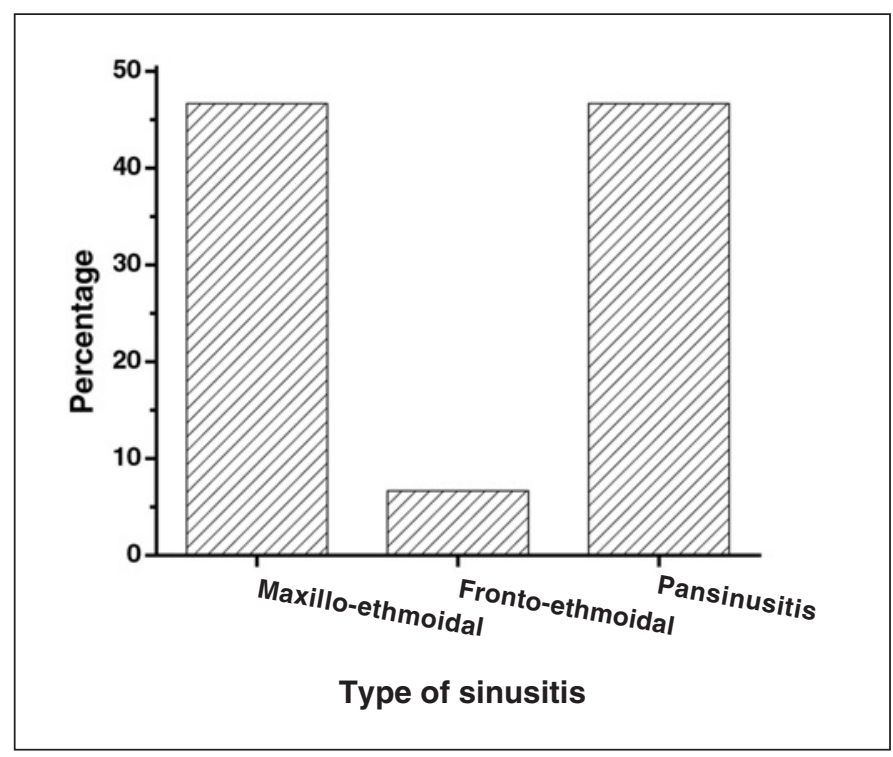

Figure 2 - Distribution of type of sinusitis in 45 patients with orbital cellulitis 
in Figure 5, subperiosteal abscesses were diagnosed in 28 patients $(62.23 \%)$. The detached periosteum was usually well demarcated, defining the border of fluid collection. In 9 patients $(20 \%)$ there was a diffuse fat infiltration at the boundaries of periorbita elevation (Figure 6). Orbital abscesses were seen in 6 patients (13.33\%, Figure 7). All of these cases were surgically confirmed.

\section{DISCUSSION}

In 1937, Hubert published a classification of sinusitis complications which included palpebral, orbital and intracranial

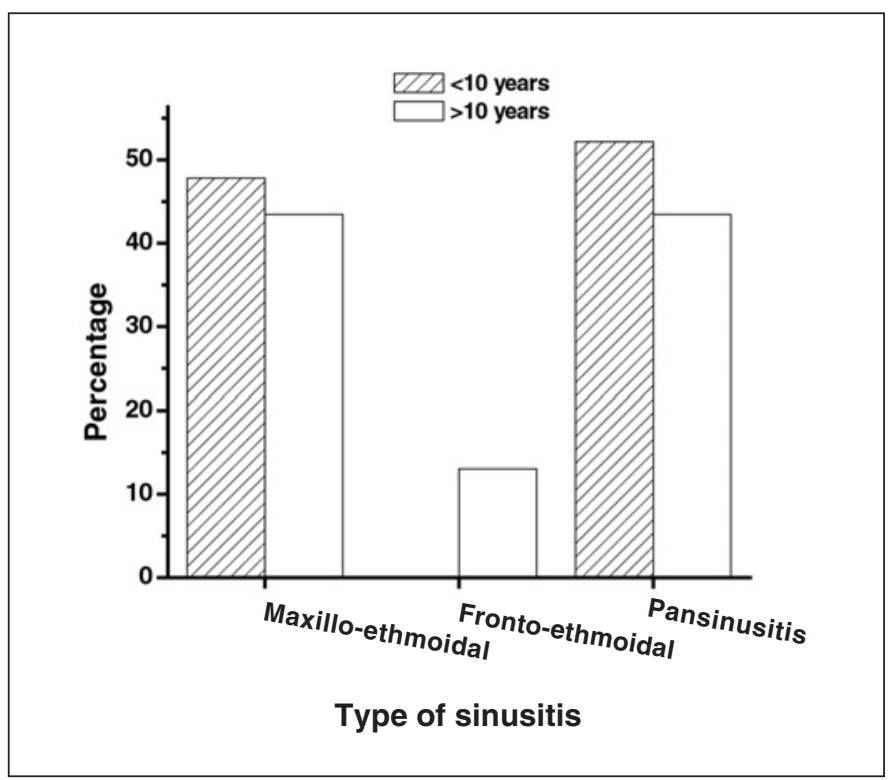

Figure 3 - Comparison of type of sinusitis in patients with orbital cellulitis due sinusitis according to age

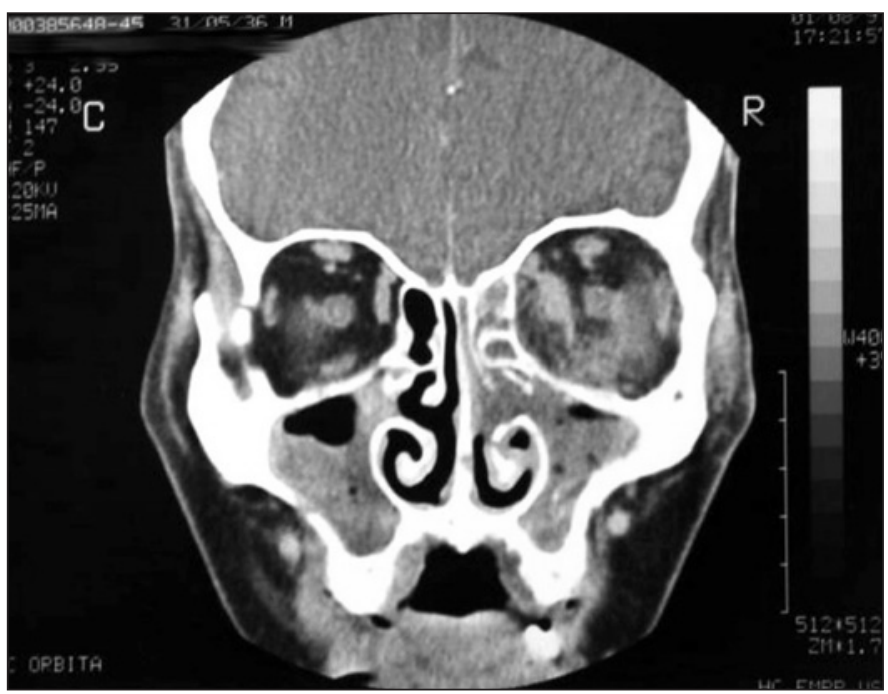

Figure 4 - Coronal scan of computed tomography of the orbit showing a diffuse cellulitis in right orbit diseases ${ }^{(7)}$. According to the Hubert scheme, complications derived from sinusitis could be staged as: I - inflammatory edema of the eyelids, II - subperiosteal abscess of the orbit, III - diffuse orbital cellulitis, IV - orbital abscess and V - thrombophlebitis of the cavernous sinuses.

Category $\mathrm{V}$ is obviously not a form of orbital cellulitis. In fact, it is an extremely rare form intracranial complication of sinusitis $^{(24-25)}$ and should not be classified as a subtype of orbital cellulitis. Hubert's description of group I was confusing, including eyelid and orbital signs in the same category, as textually quoted: in the first group the infection is confined to the nasal sinuses, and there is only an inflammatory edema of the lids which may become markedly swollen. The edema

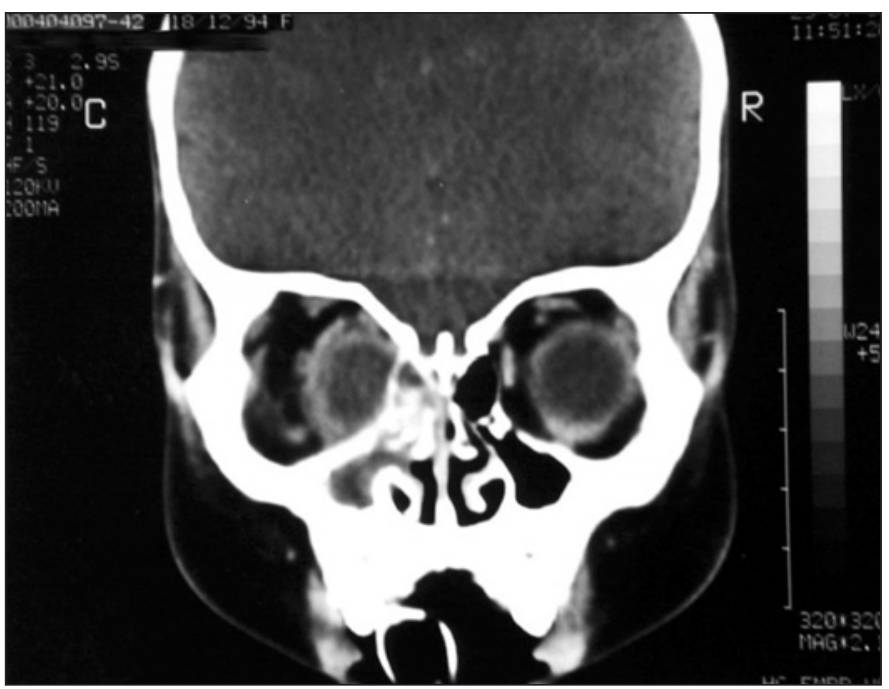

Figure 5 - Coronal scan of computed tomography of the orbit showing an isolated subperiosteal abscess of the medial wall. Note the well delineated detachment of the ethmoidal periorbita. The orbital fat is not involved.

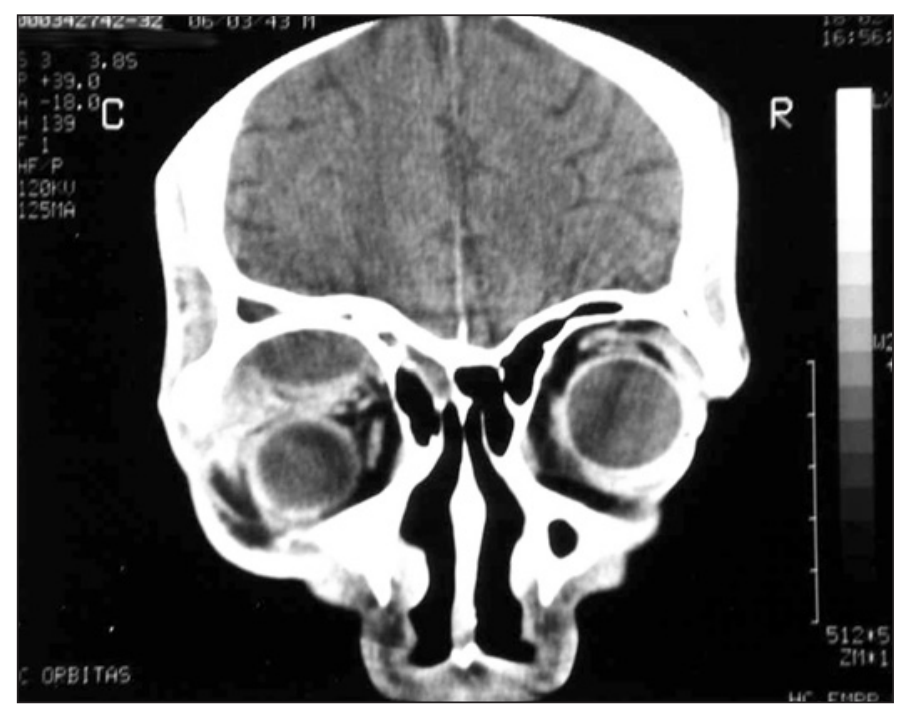

Figure 6 - Coronal scan of computed tomography of the orbit showing a subperiosteal abscess associated with diffuse infiltration. Note detachment of the roof periorbita plus a halo of increased fat density in roof of left orbit. 


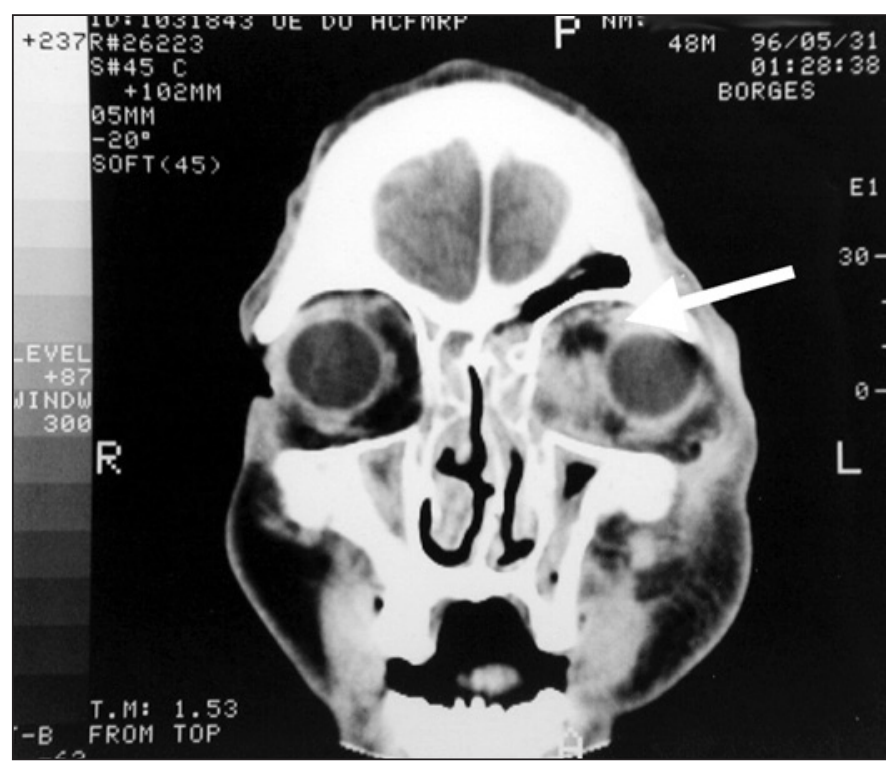

Figure 7 - Coronal scan of computed tomography of the orbit showing a left orbital abscess

may, however, extend into the orbital tissue. When this occurs, a slight exophthalmos and some limitation of movement of the eyeball appear ${ }^{(7)}$. In 1948, Smith and Spencer used the Hubert classification to stage orbital complications due to sinus infection. The same imprecision concerning to the definition of group I was maintained. According to the authors, this category was defined as inflammatory edema of the eyelids with or without edema of the orbit ${ }^{(8)}$.

In 1970, Chandler et al., used the Hubert, Smith and Spencer classification to describe orbital complications of sinusitis $^{(12)}$. It should be noted that Chandler kept the Smith and Spencer definition of group I but, probably noticing the theoretical inconsistency of labeling as eyelid edema a category that includes exophthalmos and eye motility restriction, he removed the word eyelid from this category. Chandler also modified the definition of category III. While for Smith this category was due to phlebitis of the orbital veins, Chandler used the expression "diffuse cellulitis" to describe orbital fat infiltration by inflammatory cells ${ }^{(12)}$. After Chandler's article, the Hubert, Smith \& Spencer classification was overlooked and the vast majority of authors referred to the classification of orbital infections due to sinusitis as Chandler's classification $^{(19-20,26-30)}$.

Moloney et al., introduced a great deal of confusion in the terminology of orbital infections when they used the words "preseptal" or periorbital, that by definition describe extraorbital conditions, for stage infections within the orbit ${ }^{(10)}$. Several authors also described group I of Chandler's classification as "preseptal cellulitis"(20,26-27,29,31).

We think that the use of the term "preseptal cellulitis" to describe group I of Chandler's classification is not appropriate.

In order to avoid imprecisions, diseases that occur within the orbit or in its vicinity should be described by terms with specific meanings. By definition, any orbital disease is a pathologic process that is post- or retroseptal or, in other words, confined to the space behind the septum. Conversely, a preseptal disease is always located anteriorly to the septum and thus is a pure eyelid or palpebral process. Diseases that occur on both sides of the septum can be labeled as orbito-palpebral and, finally, any disease that occurs outside but close to the orbits, such as in the eyelids and/or around the bone orbital walls may be named as periorbital owing to the fact that the Latin prefix peri means around.

It is doubtful if a sinusitis can provoke an eyelid infiltration or edema without compromising the orbit. The major venous outflow from the sinuses is to the sphenopalatine veins and pterygoid plexus that enter the internal jugular system. Venous drainage also occurs to the ethmoid veins through the orbital plexus to the cavernous sinuses. A relatively minor drainage is to the facial veins which have tributaries from veins that drain from the eyelids ${ }^{(32)}$. So, as pointed out by Harris, an elevated pressure in the sinus veins could be transmitted to both orbit and eyelids and never to the eyelids alone $^{(30)}$.

We think that category I of the Hubert, Smith and Spencer and Chandler orbital infection classifications should not designed as preseptal, eyelid or periorbital cellulitis. The socalled orbital cellulitis group I must be understood as a stage of a process that is already happening within the orbit. At the time of the establishment of the first orbital cellulitis classification, CT scans were not available and the concept of category I might have been used to describe the initial stages of any type of cellulitis. In our experience, whenever a clinical diagnosis of orbital infection is made, intraorbital changes can be detected by CT scans ${ }^{(33)}$ either as a diffuse infiltration of the orbital fat, or a detachment of the periorbita (subperiosteal abscess) or a true orbital abscess.

Differentiating types of cellulitis based on their CT appearance helps the clinician to establish guidelines for the management of specific cases.

In our opinion, orbital abscesses should be drained without any delay. It is well known that intravenous antibiotics can penetrate the abscess ${ }^{(34)}$, but without drainage their antibacterial activity within the abscess is poor, probably because the purulent milieu protects the microorganisms by enzymatic degradation of antibiotics ${ }^{(35-36)}$. Therefore the risk of such cases to originate intracranial complications is high. In addition, an orbital abscess provokes a rapid expansion of the orbital contents, carrying a extremely high risk of visual impairment.

Subperiosteal abscesses can also lead to intracranial complications and to visual impairment ${ }^{(37-38)}$. However, this condition has distinct characteristics. The fluid collection is limited by the periorbita with varying amounts of fat infiltration beyond the well demarcated border of the detached periorbita. It is well known that in some cases of periorbita detachment there is no pus between the bone wall and the periorbita, the periosteum elevation being caused by hemorrhagic or clear fluid and edema ${ }^{(39)}$. 
The decision about the necessity and timing of a subperiosteal abscess surgical drainage is complex and involves the assessment of many factors including response to the antibiotic treatment, age, size and location of the fluid collection ${ }^{(40)}$.

Finally we believe that diffuse fat infiltration can be understood as an initial stage in the continuum of orbital infection forms. As there is no true abscess, these cases can be managed with antibiotics alone. Careful follow-up of the clinical response to therapy will dictate the need for further imaging studies and for an eventual surgical drainage if a subperiosteal or intraorbital abscess is formed.

\section{CONCLUSIONS}

Computed tomography is essential for staging orbital cellulitis. It allows a clear differentiation of the inflammatory process that is occurring in the orbit and shows how the orbital contents are being affected by infection. The terms preseptal or periorbital should not be used to describe orbital infections.

\section{RESUMO}

Objetivo: Descrever os achados tomográficos em celulites orbitárias secundárias à sinusite. Métodos: Os prontuários e filmes tomográficos de 45 pacientes consecutivos com celulite orbitária secundária à sinusite tratados no Hospital das Clínicas da Faculdade de Medicina de Ribeirão Preto foram analisados por um radiologista e dois cirurgiões de órbita. Resultados: Três principais tipos de alterações tomográficas foram observadas: infiltração difusa da gordura, abscesso subperiósteo e abscesso orbitário. Infiltração difusa da gordura (caracterizada por aumento da densidade da gordura extra ou intraconal) foi vista em 11 pacientes $(24,44 \%)$. Abscesso subperiósteo foi diagnosticado em 28 pacientes $(62,23 \%)$. Abscesso orbitário comprovado cirurgicamente foi detectado em 6 pacientes $(13,33 \%)$. Conclusões: Em todos os casos de celulite orbitária secundária à sinusite foram detectadas mudanças intra-orbitárias na tomografia computadorizada: infiltração difusa da gordura orbitária, descolamento da periórbita (abscesso subperiósteo) ou abscesso orbitário verdadeiro. A categoria I da classificação de celulite orbitária de Chandler (edema inflamatório) deve ser entendida como estágio de um processo que já está ocorrendo dentro da órbita. Nesse sentido, a expressão "celulite préseptal" que designa infecção palpebral não deve ser usada para nomear a categoria I da classificação de Chandler.

Descritores: Celulite/etiologia; Sinusite/complicações; Órbita; Abscesso; Tomografia computadorizada por raio- $\mathrm{X}$

\section{REFERENCES}

1. Ford JG, Yeatts RP, Givner LB. Orbital cellulitis, subperiosteal abscess, sinusitis, and septicemia caused by Arcanobacterium haemolyticum. Am J Ophthalmol. 1995;120(2):261-2.
2. Hemady R, Zimmerman A, Katzen BW, Karesh JW. Orbital cellulitis caused by Eikenella corrodens. Am J Ophthalmol. 1992;114(5):584-8. Comment in: Am J Ophthalmol. 1993;115(3):398-9.

3. Karr DJ, Weinberger E, Mills RP. An unusual case of cellulitis associated with a Molteno implant in a 1-year-old child. J Pediatr Ophthalmol Strabismus. 1990;27(2):107-10.

4. Gold SC, Arrigg PG, Hedges TR 3rd. Computerized tomography in the management of acute orbital cellulitis. Ophthalmic Surg. 1987;18(10):753-6.

5. Jayamanne DG, Bell RW, Allen ED. Orbital cellulitis-an unusual presentation and late complication of severe facial trauma. Br J Oral Maxillofac Surg. 1994;32(3):187-9.

6. Rumelt S, Rubin PA. Potential sources for orbital cellulitis. Int Ophthalmol Clin. 1996;36(3):207-21.

7. Hubert L. Orbital infections due to nasal sinusitis. N Y State J Med. 1937;37: 1559-64.

8. Smith AT, Spencer JT. Orbital complications resulting from lesions of the sinuses. Ann Otol Rhinol Laryngol. 1948;57:5-27.

9. Mortimore S, Wormald PJ. The Groote Schuur hospital classification of the orbital complications of sinusitis. J Laryngol Otol. 1997;111(8):719-23.

10. Moloney JR, Badham NJ, McRae A. The acute orbit. Preseptal (periorbital) cellulitis, subperiosteal abscess and orbital cellulitis due to sinusitis. J Laryngol Otol Suppl. 1987;12:1-18.

11. Anselmo-Lima WT, Cruz AAV. Complicações das sinusites. In: Sih T, Ramos BD, Sakano E, Endo LH, editores. Otorrinolaringologia pediátrica. Rio de Janeiro: Revinter; 1998. p.322-6.

12. Chandler JR, Langenbrunner DJ, Stevens ER. The pathogenesis of orbital complications in acute sinusitis. Laryngoscope. 1970;80(9):1414-28.

13. Healy GB. Chandler et al.: "The pathogenesis of orbital complications in acute sinusitis". (Laryngoscope. 1970;80(9):1414-28). Laryngoscope. 1997;107(4): 441-6). Comment on: Laryngoscope. 1970;80(9):1414-28

14. Skedros DG, Haddad J Jr, Bluestone CD, Curtin HD. Subperiosteal orbital abscess in children: diagnosis, microbiology, and management. Laryngoscope. 1993;103(1 Pt 1):28-32.

15. Deutsch E, Eilon A, Hevron I, Hurvitz H, Blinder G. Functional endoscopic sinus surgery of orbital subperiosteal abscess in children. Int J Pediatr Otorhinolaryngol. 1996;34(1-2):181-90.

16. Reddy SC, Sharma HS, Mazidah AS, Darnal HK, Mahayidin M. Orbital abscess due to acute ethmoiditis in a neonate. Int $\mathbf{J}$ Pediatr Otorhinolaryngol. 1999;49(1):81-6.

17. Gurucharri MJ, Lazar RH, Younis RT. Current management and treatment of complications of sinusitis in children. Ear Nose Throat J. 1991;70(2):107-12.

18. Swift AC, Charlton G. Sinusitis and the acute orbit in children. J Laryngol Otol. 1990;104(3):213-6.

19. Goldberg F, Berne AS, Oski FA. Differentiation of orbital cellulitis from preseptal cellulitis by computed tomography. Pediatrics. 1978;62(6):1000-5.

20. Schramm VL Jr, Curtin HD, Kennerdell JS. Evaluation of orbital cellulitis and results of treatment. Laryngoscope. 1982;92(7 Pt 1):732-8.

21. Ognibene RZ, Voegels RL, Bensadon RL, Butugan O. Complications of sinusitis. Am J Rhinology. 1994;8(4):175-9.

22. Tovi F, Gatot A, Hertzanu YCT. Demonstration of metastatic anaerobic orbital abscess. J Laryngol Otol. 1991;105(12):1086-8.

23. Choi S, Lawson W, Urken ML. Subperiosteal orbital hematoma. An unusual complication of sinusitis. Arch Otolaryngol Head Neck Surg. 1988;114(12): 1464-6.

24. Clayman GL, Adams GL, Paugh DR, Koopmann CF Jr. Intracranial complications of paranasal sinusitis: a combined institutional review. Laryngoscope. 1991;101(3):234-9. Comment in: Laryngoscope. 1991;101(11):1245.

25. Rogano LA, Tella Jr O, Suriano I, Braga FM, Manso PG. Abscesso intraorbitário e intracraniano por "Aspergillus fumigatus". Arq Bras Oftalmol. 1990;53 (2):92-6.

26. Gellady AM, Shulman ST, Ayoub EM. Periorbital and orbital cellulitis in children. Pediatrics. 1978;61(2):272-7.

27. Clary R, Weber AL, Eavey R, Oot RF. Orbital cellulitis with abscess formation caused by sinusitis. Ann Otol Rhinol Laryngol. 1988;97(2 Pt 1):211-2. Comment in: Ann Otol Rhinol Laryngol. 1989;98(4 Pt 1):322.

28. Welsh LW, Welsh JJ. Orbital complications of sinus disease. Laryngoscope 1974;84(5):848-56.

29. Souliere CR Jr, Antoine GA, Martin MP, Blumberg AI, Isaacson G. Selective non-surgical management of subperiosteal abscess of the orbit: computerized tomography and clinical course as indication for surgical drainage. Int J Pediatr Otorhinolaryngol. 1990;19(2):109-19. Comment in: Int J Pediatr Otorhinolaryngol. 1991;21(3):277-9. Int J Pediatr Otorhinolaryngol. 1993;25(1-3):277-8. 
30. Harris GJ. Subperiosteal abscess of the orbit. Arch Ophthalmol. 1983;101(5): 751-7.

31. Clary RA, Cunningham MJ, Eavey RD. Orbital complications of acute sinusitis: comparison of computed tomography scan and surgical findings. Ann Otol Rhinol Laryngol. 1992;101(7):598-600.

32. Anon JB, Rontal M, Zinreich SJ. Neurovascular anatomy of the paranasal sinuses. In: Anon JB, Rontal M, Zinreich SJ, editors. Anatomy of the paranasal sinuses. New York: Thieme; 1996. p.35-44.

33. Santos AC, Prado PTC, Cruz AAV. Órbita II - imagem. Arq Bras Oftalmol 1999;622:208-19.

34. Yamamoto M, Jimbo M, Ide M, Tanaka N, Umebara Y, Hagiwara S. Penetration of intravenous antibiotics into brain abscesses. Neurosurgery. 1993;33(1): 44-9.
35. Galandiuk S, Lamos J, Montgomery W, Young S, Polk HC Jr. Antibiotic penetration of experimental intra-abdominal abscesses. Am Surg. 1995;61(6): 521-5.

36. Black P, Graybill JR, Charache P. Penetration of brain abscess by systemically administered antibiotics. J Neurosurg. 1973;38(6):705-9.

37. Hamilton RC. A discourse on the complications of retrobulbar and peribulbar blockade. Can J Ophthalmol. 2000;35(7):363-72.

38. Harris GJ. Subperiosteal abscess of the orbit. Age as a factor in the bacteriology and response to treatment. Ophthalmology. 1994;101(3):585-95.

39. Harris GJ. Subperiosteal inflammation of the orbit. Bacteriological analysis of 17 cases. Arch Ophthalmol 1988;106(7):947-52.

40. Garcia GH, Harris GJ. Criteria for nonsurgical management of subperiosteal abscess of the orbit: analysis of outcomes 1988-1998. Ophthalmology. 2000; 107(8):1454-6; discussion 1457-8.
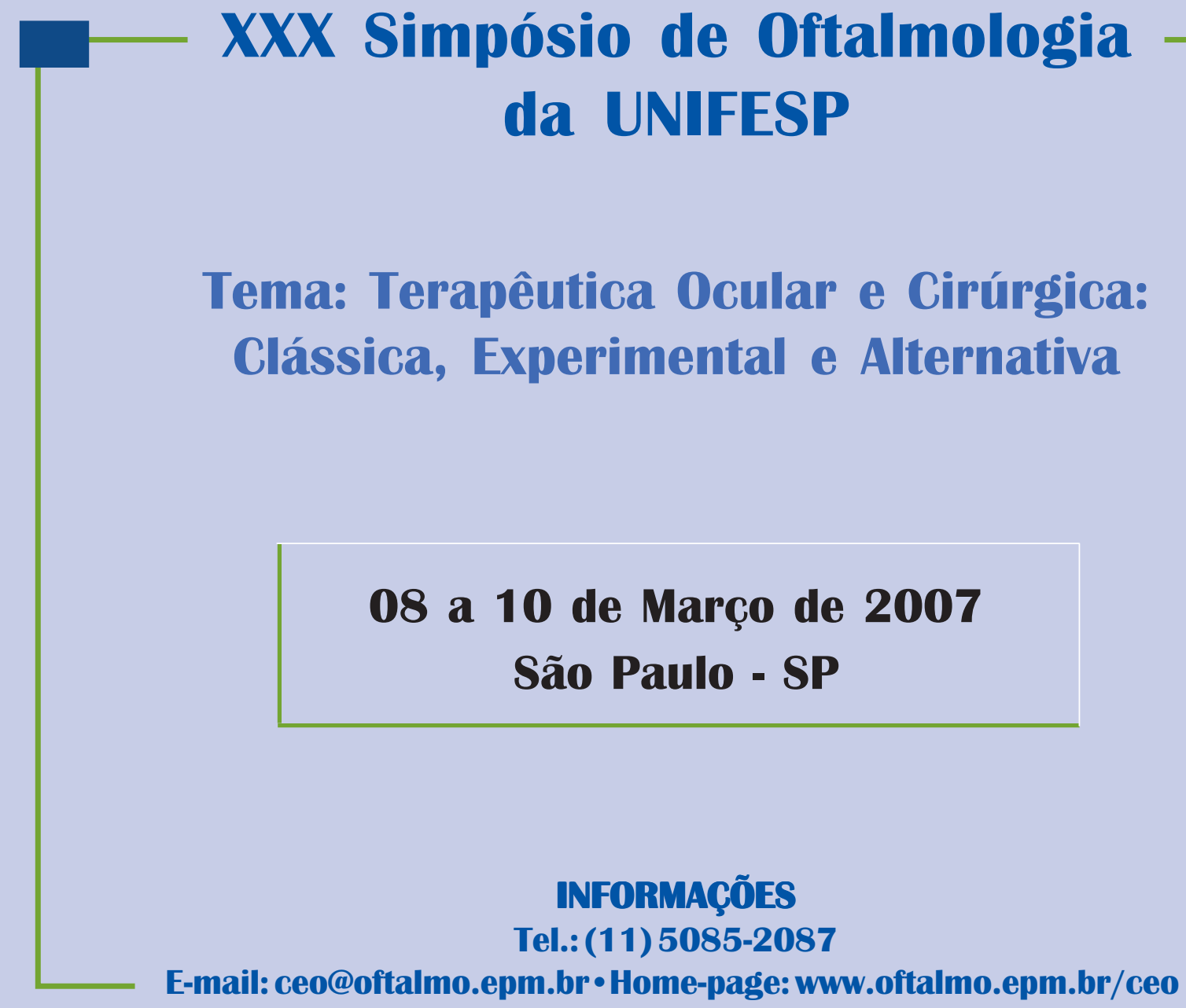

E-mail: ceo@oftalmo.epm.br•Home-page: www.oftalmo.epm.br/ceo 